\title{
IMPLEMENTASI ALGORITMA GREEDY PADA METODE TRANSPORTASI DENGAN MENGGUNAKAN VAM DALAM PENDISTRIBUSIAN PRODUK
}

\author{
Ribangun Bamban Jakaria, Mochamad Alfan Rosid \\ Teknik Informatika Universitas Muhammadiyah Sidoarjo Indonesia \\ ribangunbz@Umsida.ac.id ; alfanrosid@umsida.ac.id
}

\begin{abstract}
Abstrak
Perusahaan seringkali dihadapkan pada persoalan pendistribusian produk ke tujuan (outlet), sehingga masalah yang sering muncul adalah pertama, adanya kepastian pengiriman ke outlet, kedua perusahaan harus menghitung biaya distribusi untuk mendapatkan biaya yang efisien sehingga perioritas pendistribusian berdasarkan jarak sumber dengan outlet, ketiga waktu. Dari uraian masalah tersebut perlunya solusi sehingga pertama, armada yang dimiliki perusahaan harus mampu menjangkau titik-titik outlet secara rutin, kedua memudahkan dalam melakukan evaluasi atas pendistribusian produk tersebut secara cepat dan realtime, dengan permasalahan dan solusi tersebut tersebut, perlunya penggunaan Smartphone sebagai pengendali sistem distribusi, selanjutnya mengaplikasikan metode Transportasi untuk menentukan jalur tercepat suatu rute distribusi, serta, mengatur pola distribusi dengan metode Vogel's dengan mengimplementasi algoritma Greedy. Sehingga perusahaan mampu menyelesaikan pemenuhan atas produk pada outlet secara cepat dan selanjutnya perusahaan dapat melakukan penjadwalan ulang pengiriman berikutnya.
\end{abstract}

Kata kunci: Algoritma Greedy, metode Transportasi, Distribusi, VAM

\section{PENDAHULUAN}

Perusahaan sering kali dihadapkan pada persoalan distribusi produk dari pabrik (sumber) ke tujuan (outlet). Hal ini disebabkan saluran pemasaran merupakan suatu fungsi dan sistem jaringan perantara yang terorganisir melakukan semua aktivitas pemasaran yang diperlukan untuk menghubungkan produsen dengan konsumen. Sementra jumlah produk yang didistribusikan, outlet yang akan menjadi tujuan dan armada yang digunakan adalah sebagai masalah transportasi (Ghozalidkk, 2012). Tujuannya untuk meminimalkan biaya pengiriman barang dari sumber ke tujuan (outlet) (Tjutjudkk, 2003) supaya kebutuhan masing-masing daerah tujuan akan terpenuhi di setiap lokasi pasokan sesuai kapasitas(Mandel, 2004)(Reebdan Leavegood, 2002) sehingga dengan memindahkan produk/barang atau jasa secara efektif dan efesien pada titik supply ke titik permintaan akan memberikan potensi peningkatan keuntungan bagi perusahaan (Mandel, 2004)(Reebdan Leavegood, 2002).

Pencarian rute terpendek menggunakan Algoritma Greedy rumusan masalah pada penelitian tersebut adalah bagaimana mencari rute terpendek dari node A (kecamatan Ngaliyan) ke node L (kecamatan Sampangan) dari jarak yang ditempuh, pendekatan yang dilakukan adalah dengan membuat pilihan pada setiap langkah dan diharapkan akan mendapatkan solusi optimum(Hayatidkk, 2014),Sementara pada “ Aplikasi Metode Transportasi dalam optimasi biaya distribusi beras miskin (raskin) pada PERUM Bulog sub drive Medan (Simbolondkk, 2014), hasil yang diperoleh pada penggunaan metode transportasi tersebut adalah mampu memberikan penghematan atau efisiensi biaya distribusi beras miskin (raskin), dimana metode yang digunakan Vogel's (VAM) untuk memperoleh solusi fisibel awal dan modifird Distribition (MODI) untuk analisis perolehan nilai optimum pada pendistribusian raskin tersebut. Dari dua Penelitian telah dilakukan tersebut diatas maka penulis melakukan penelitian yang bertujuan untuk mengurangi biaya pendistribusian dengan melakukan perancangan sistem informasi pendistribusian produkdengan menggunakan metode Transportasi dengan metode Vogel's (VAM), dengan cara mengimplementasikan Algoritma Geedy, penggunaan Android,bertujuan untuk membantu mempercepat prosespenyelesaian pendistribusian, sementara penggunaan Algoritma Greedy adalah sebuah algoritma yang melibatkan pencarian sebuah himpunan bagian kandidat yang 
dalam hal ini harus memenuhi beberapa kreteria yang ditentukan yaitu menyatakan suatu solusi dan optimasi oleh suatu objek, sehingga akan membantu dalam menentukan jumlah produk yang akan didistribusikan ke beberapa tujuan dari beberapa sumber. Dalam penggunaan metode transportasi yaitu Vogel's maka peran Algoritma Greedy membentuk solusi langkah,yaitu menentukan titik distribusi yang terpilih, terdapat banyak pilihan yang perlu diekspolarasi oleh karena itu pada setiap langkah harus dibuat keputusan yang terbaik dalam menentukan pilihan. Hingga semua kapasitas dan kebutuhan masing-masing sumber dan tujuan telah terdistribusi secara penuh.

\section{METODOLOGI PENELITIAN}

\section{A. Teknik Pengumpulan Data}

Fokus penelitian yang dilakukan adalah untuk menghasilkan rute distribusi produk yang optimal dengan menggunakan algoritmagreedy. Teknik pengumpulan data yang digunakan adalah :

1. Study Literatur

Peneliti mempelajari teori tentang algoritma greedy dari berbagai sumber yang ada seperti jurnal ilmiah, artikel, makalah dan situs-situs di internet.

2. Wawancara

Wawancara dilakukan untuk mendapatkan data secara rinci yaitu berupa data pemesanan produk dari sejumlah outlet yang diterima melalui hasil take order sales ataupun order yang diterimakan dari customerservice.

3. Observasi

Kegiatan ini dilakukan untuk mensinkronkan hasil wawancara yang diperoleh dengan melakukan observasi langsung kelapangan untuk memastikan data yang diperoleh valid.

\section{B. Perancangan dan Pembuatan Sistem}

Perancangan sistem merupakan bagian yang penting dalam membuat suatu sistem ataupun aplikasi, perancangan sistem ini dimaksudkan untuk memberikan gambaran umum tentang aplikasi yang akan dibuat. 


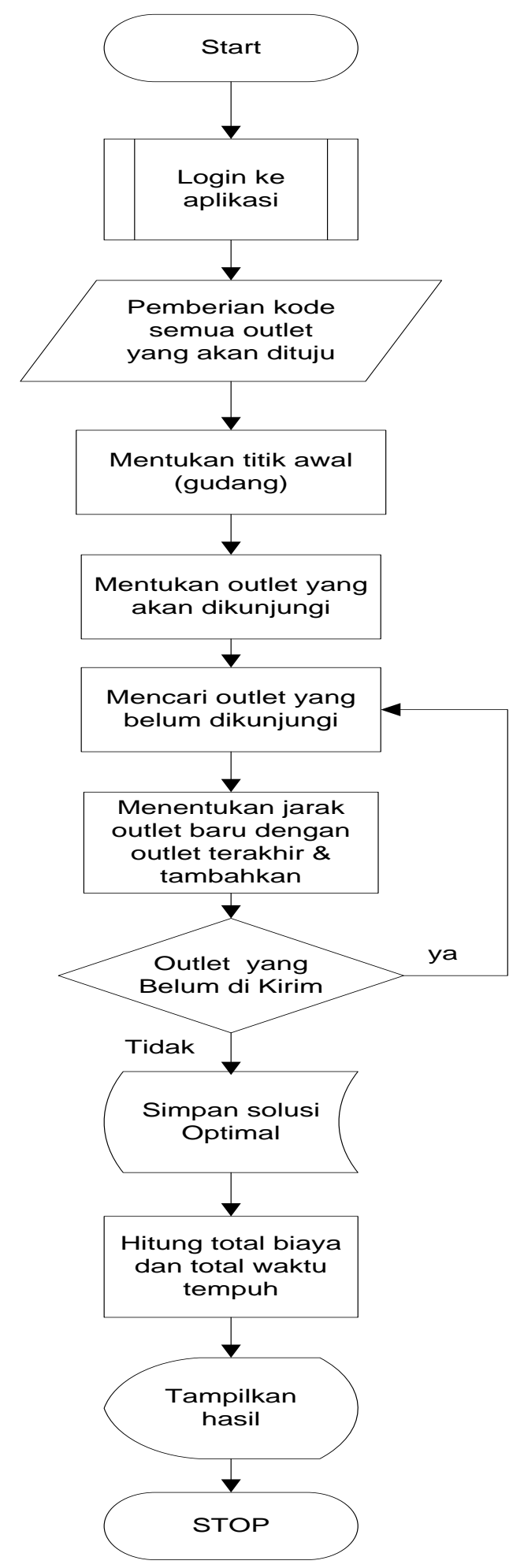

Gambar 1 : Flowchart Perancangan dan Pembuatan Sistem 


\section{Use Case Diagram}

Padause casediagram yang di tunjukkangambar 2, dijelaskanmengenai proses apasaja yang dilakukanolehpengguna.

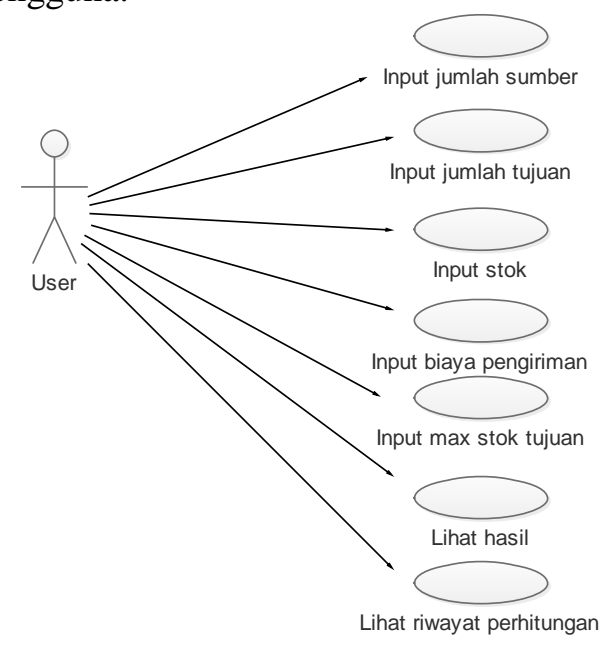

Gambar 2: Use Case Diagram

\section{HASIL DAN PEMBAHASAN}

\section{A. Implementasi}

Aplikasi ini bertujuan untuk menyelesaikan masalah-maslah transportasi dengan menggunakan Vogel's yang bertujuan untuk memperoleh biaya yang optimum

\section{B. Implementasi form}

Dalam mengimplementasikan aplikasi yang dibuat memiliki tampilan antar muka untuk mempermudah pengguna dalam menggunakan Aplikasi.

1. Menu utama

Saat pertama user membuka aplikasi transpotasi, maka aplikasi akan menampilkan main activity.

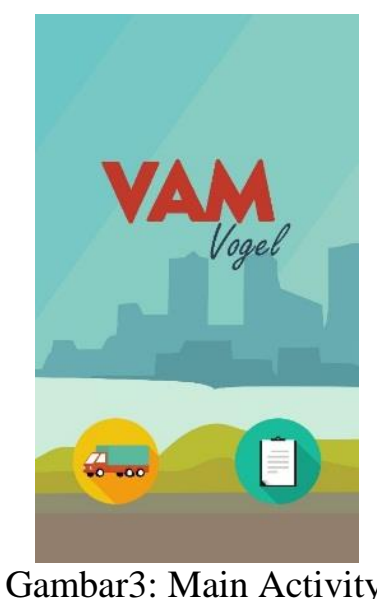

Main activity merupakan menu utama pada yang terdiri dari 2 (dua) menu yaitu pertama, melakukan penghitungan biaya transportasi, menu yang kedua adalah untuk melihat riwayat dari perhitungan yang telah dilakukan sebelumnya.

2. Jumlah sumber dan tujuan

Tampilan tersebut merupakan tampilan yang digunakan oleh user untuk mengimputkan jumlah sumber dan tujuan yang ada 

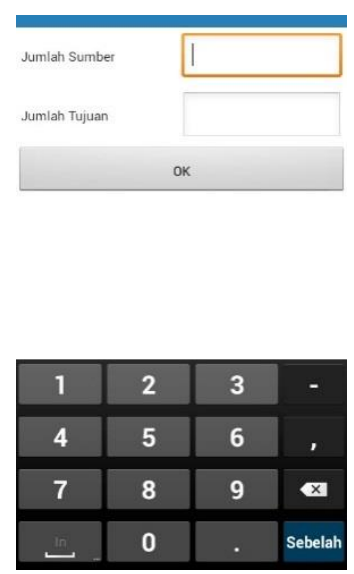

Gambar4:Jumlah Sumber dan Tujuan Activity

3. Proses Input

Berikut fasilitas utama aplikasi ini, yaitu input data yang harus dimasukkan setelah melakukan input jumlah sumber dan tujuan.

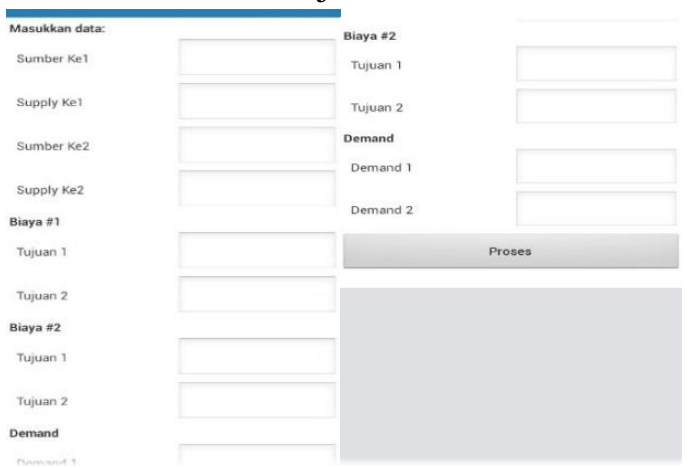

Gambar 5 : Detail input activity

Dengan melakukan input secara detail pada sumber, tujuan, deman, kapasitas, biaya distribusi setiap tujuan selanjutnya diproses dengan metode Vogel's untuk menghasilkaan jalur distribusi dan biaya yang optimum.

4. Route dan Pendistribusian

Pada saat menu proses dilakukan maka aplikasi akan menampilkan data distribusi ke tujuan dan jumlah barang yang terdistribusikan sesuai dengan jarak terdekat.

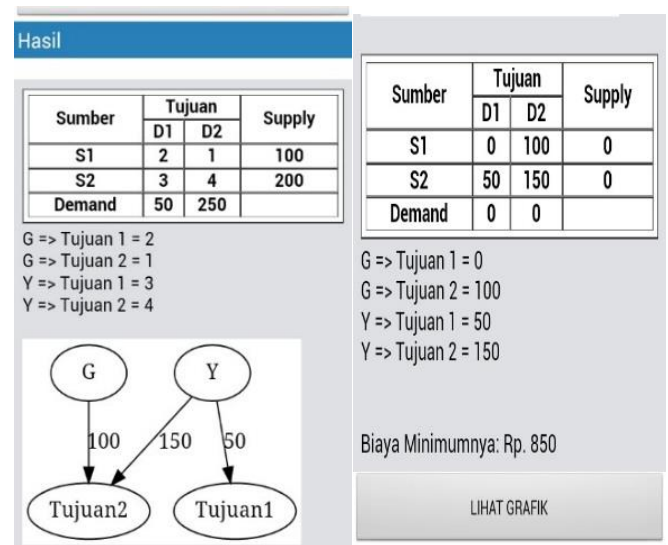

Gambar 6 : Hasil Optimalisasi dengan Vogel 
5. Riwayat

Pada menu riwayat semua aktivitas yang telah dilakukan dalam menggunakan aplikasi ini akan tersimpan. Untuk dapat mengetahui pendistribusian yang telah dilakukan, maka user mengklik data riwayat yang berisikan tanggal dan waktu penggunaan sehingga ketika di klik akan muncul data inputan sumber, tujuan, biaya pengiriman, deman, kapasitas serta hasil proses yang berupa tabel dan nilai perhitungan biaya yang dihasilkan secara optimum.

Untuk menghapus riwayat dengan mengklik kemudian tahan selanjutnya akan muncul pemberitahuan di hapus atau tidak.

Riwayat
25/Februari/2016
13:20:30 malam
Todyoganglok
25/Februari/2016
13:40:06 malam
25/Februari/2016
13:55:20 malam
6. 26/Februari/2016
07:35:47 pagi

Gambar 7: Riwayat Penggunaan Aplikasi

6. Bantuan

Bantuan pada menu utama berisikan 2 pilihan menu yaitu Tutorial dan aplikasi, masing memiliki fungsi yang berbeda untuk menu Tutorial yaitu menu yang berisikan informasi tentang cara penggunaan dan menu aplikasi berisikan tentang deskripsi singkat tentang aplikasi.

7. Membuat APK

Pembuatan file (.apk) pada aplikasi android betujuan agar aplikasi dapat dipasang pada perangkat telepon android manapun

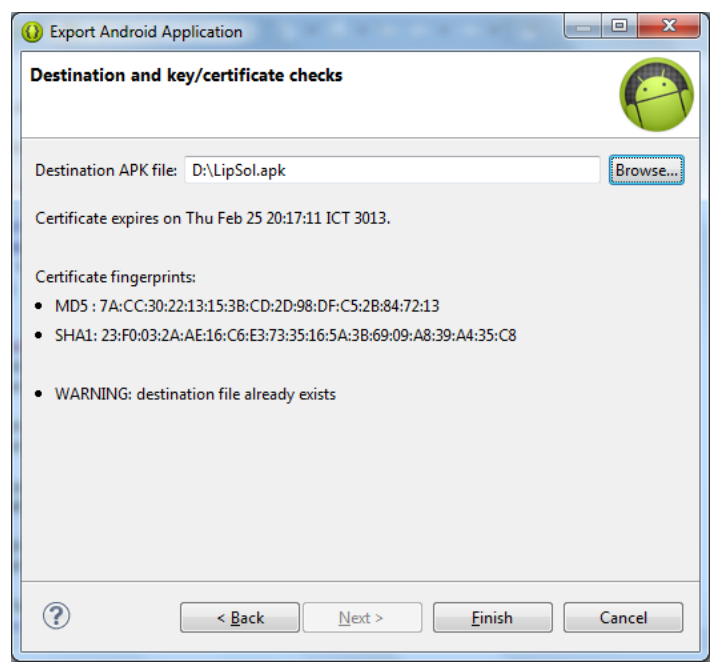

Gambar 8. Pembuatan file apk 
Langkah pembutan file apk yaitu dengan mengklik kanan aplikasi kemudian pilih android Tools > exsport Signed Application Package dan lakukan hingga langkah terakhir.

8. Instalasi

Langkah instalasi file (.apk) pada perangkat android dilakukan dengan mencari file apk pada ponsel kemudian menggunakan fasilitas file manager, selanjutnya klik aplikasi tersebut dan pilih instal

9. Pengujian

Pada pengujian yang telah dilakukan dengan menggunakan aplikasi ini, bertujuan untuk mengetahui apakah aplikasi ini dapat menghitung nilai secara optimum padapendistribusian produk AMDK.

Dari hasil pengujian didapat hasil seperti yang diperlihatkan pada gambar 8 .

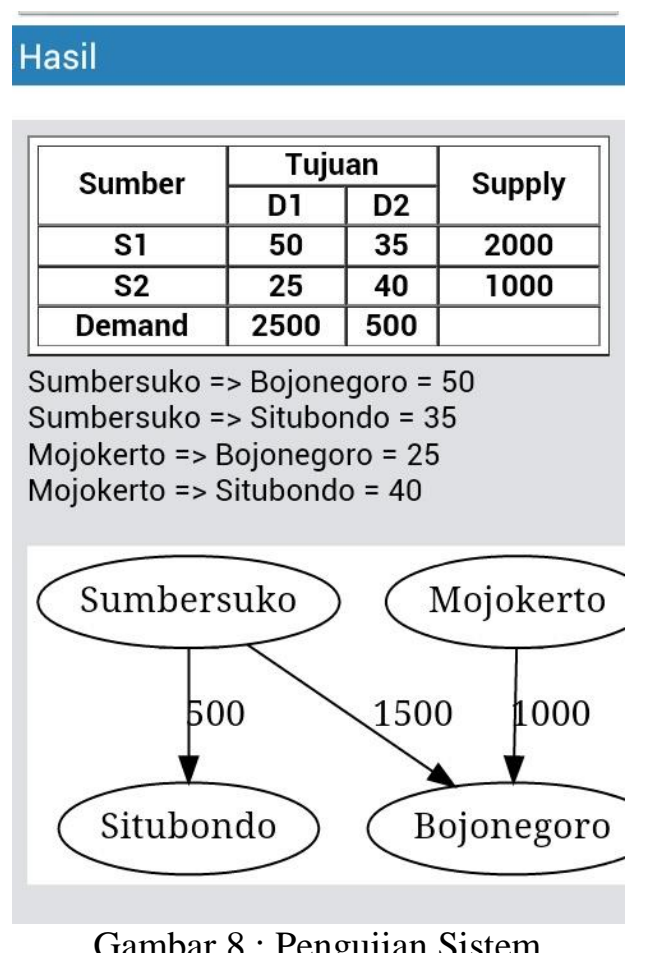

\section{KESIMPULAN DAN SARAN}

\section{A. Kesimpulan}

Berdasarkan pengujian yang telah dilakukan pada aplikasi sistem pendistribusian ini, dapat disimpulkan bahwa :

1. Sistem aplikasi ini berjalan dengan baik

2. Penghitungan biaya pendistribusian dapat dilakukan dengan cepat

3. Algoritma greedy dapat membantu proses pendistribusian produk AMDK ke outlet yang dituju dengan hasil yang optimum

4. Lokasi outlet dan biaya yang akan dikeluarkan secara cepat diketahui, sehingga perusahaan mampu memprediksi biaya yang akan dikeluarkan.

5. Karena dijalankan dengan menggunakan android maka user dapat melakukan penghitungan tanpa dibatasi waktu dan tempat karena dilakukan secara mobile. 


\section{B. Saran}

Guna penyempurnaan aplikasi ini ke depan maka penulis memberikan saran sebagai berikut :

1. Kemampuan aplikasi dalam memproses pendistribusian produk bergantung pada kemampuan ponsel yang dimiliki.

2. Aplikasi pendistribusian ini hanya dapat memproses jika jumlah sumber sama dengan jumlah tujuan.

\section{DAFTAR PUSTAKA}

[1] Ghozali, zulkipli dkk, 2012, Optimal solution of Transportation problem using programming : a case of Malaysia Trading company, University teknologi Petromas, Bandar sri Iskandar.

[2] Tjutju TD, dkk., Operations Research : Model-model pengambilan keputusan, sinar baru algensindo, 2003

[3] Mandel, JK, 2004, cutting your distributions cost browing your business, price water house coopers.

[4] Hayati, Enty Nur Dkk, 2014, pencarian rute terpendek menggunakan algoritma greedy, Seminar Nasional IENACO ISSN: 2337-4349

[5] Simbolon, L.D, Situmorang, M \& Napitupulu, N, 2014 “ Aplikasi Metode Transportasi dalam optimasi biaya distribusi beras miskin (raskin) pada PERUM Bulog sub drive Medan" (saintia Matematika) vol 02, 03, 2337-9197

[6] Reeb, J and S, Leavegood, 2002, Transportations Problem : A Special case for linier programming problem, Operations Research, Oregon State University. 